\title{
Role of reactive oxygen species and isoflavonoids in soybean resistance to the attack of the southern green stink bug
}

\author{
Ivana Sabljic $^{1,2}$, Jesica A Barneto $^{1}$, Karina B Balestrasse ${ }^{1}$, Jorge A Zavala $^{1}$, Eduardo A Pagano ${ }^{\text {Corresp. } 1}$ \\ 1 Instituto de Investigaciones en Biociencias Agrícolas y Ambientales-INBA, Facultad de Agronomía, Universidad de Buenos Aires, Consejo Nacional de \\ Investigaciones Científicas y Técnicas, Ciudad Autónoma de Buenos Aires, Argentina \\ 2 GDM, Chacabuco, Buenos Aires, Argentina \\ Corresponding Author: Eduardo A Pagano \\ Email address: epagano@agro.uba.ar
}

Southern green stink bugs (Nezara viridula L.) are one of the major pests in many soybean producing areas. They cause a decrease in yield and affect seed quality by reducing viability and vigor. Alterations have been reported in the oxidative response and in the secondary metabolites in different plant species due to insect damage. However, there is little information available on soybean-stink bug interactions. In this study we compare the response of undamaged and damaged seeds by Nezara viridula in two soybean cultivars, IAC-100 (resistant) and Davis (susceptible), grown under greenhouse conditions. Pod hardness, $\mathrm{H}_{2} \mathrm{O}_{2}$ generation, enzyme activities in guaiacol peroxidase (GPOX), catalase (CAT) and superoxide dismutase (SOD) as well as lipoxygenase expression and isoflavonoid production were quantified. Our results showed a greater resistance of IAC-100 to pod penetration, a decrease in peroxide content after stink bug attack, and higher GPOX, CAT and SOD activities in seeds due to the genotype and to the genotypeinteraction with the herbivory treatment. Induction of LOX expression in both cultivars and higher production of isoflavonoids in IAC-100 were also detected. It was then concluded that the herbivory stink bug induces pathways related to oxidative stress and to the secondary metabolites in developing seeds of soybean and that differences between cultivars hold promise for a plant breeding program. 
2 Role of reactive oxygen species and isoflavonoids in 3 soybean resistance to the attack of the southern green stink bug

\author{
Ivana Sabljic ${ }^{1,2}$, Jesica Alejandra Barneto' ${ }^{1}$, Karina Beatriz Balestrasse', Jorge Alberto \\ Zavala $^{1}$, Eduardo Antonio Pagano ${ }^{1}$ \\ ${ }^{1}$ Universidad de Buenos Aires, Consejo Nacional de Investigaciones Científicas y Técnicas, \\ Instituto de Investigaciones en Biociencias Agrícolas y Ambientales-INBA, Facultad de \\ Agronomía, Buenos Aires, Argentina. \\ ${ }^{2}$ GDM, Chacabuco, Provincia de Buenos Aires. Argentina. \\ Corresponding Author: \\ Eduardo Antonio Pagano ${ }^{1}$ \\ Av. San Martin 4453, Buenos Aires, C1417DSE, Argentina \\ Email address: epagano@agro.uba.ar
}

20

21

\title{
Abstract
}

Southern green stink bugs (Nezara viridula L.) are one of the major pests in many soybean producing areas. They cause a decrease in yield and affect seed quality by reducing viability and vigor. Alterations have been reported in the oxidative response and in the secondary metabolites in different plant species due to insect damage. However, there is little information available on soybean-stink bug interactions. In this study we compare the response of undamaged and damaged seeds by Nezara viridula in two soybean cultivars, IAC-100 (resistant) and Davis (susceptible), grown under greenhouse conditions. Pod hardness, $\mathrm{H}_{2} \mathrm{O}_{2}$ generation, enzyme activities in guaiacol peroxidase (GPOX), catalase (CAT) and superoxide dismutase (SOD) as well as lipoxygenase expression and isoflavonoid production were quantified. Our results showed a greater resistance of IAC-100 to pod penetration, a decrease in peroxide content after stink bug attack, and higher GPOX, CAT and SOD activities in seeds due to the genotype and to the genotype-interaction with the herbivory treatment. Induction of $L O X$ expression in both cultivars and higher production of isoflavonoids in IAC-100 were also detected. It was then concluded that the herbivory stink bug induces pathways related to oxidative stress and to the secondary metabolites in developing seeds of soybean and that differences between cultivars hold promise for a plant breeding program.

Keywords: Plant-insect interaction - Glycine max - Nezara viridula - Oxidative stress - Herbivory - Lipoxygenase

\section{Introduction}


43 The stink bug complex is one of the most detrimental pests that affects soybean (Glycine $\max$ L.) 44 yields in many countries. In South America, the main species that impair soybean yields are 45 Nezara viridula, Piezodorus guildinii and Euschistus heros. They adversely affect seed vigor and

46

47

48

49

50

51

52

53

54

55

56

57

58

59

60

61

62

63

64

65

66

67

68

69

70

71

72

73

74

75

76

77

78

79

80

81

82

83

84

85

86

87

88 may even kill the embryo and stop germination. Brazil and Argentina are two of the most important producers of this legume and damage caused by the mentioned species can result in significant economic losses (Schaefer \& Panizzi, 2000). Soybean crops destined for seed production are less tolerant to stink bug damage than soybean crops used for animal feed (Jensen \& Newsom, 1972). While stink bugs can be controlled by spraying pesticides, there are environmental and economic issues concerning the frequent use of these products. Biological control can be mentioned as an alternative method to fight against this complex of insects. For example, the well-studied egg-parasitoid Trissolcus basalis (Wollaston) has been used successfully by farmers in Brazil (Corrêa-Ferreira \& Moscardi, 1996). However, soybean host plant resistance is an interesting strategy for managing plant breeding programs (Boerma \& Walker, 2005), and it is necessary to first understand the mechanisms related to stink bug resistance in soybean breeding lines.

The soybean cultivar IAC-100 has been defined as resistant against stink bug attack (Campos et al., 2010; McPherson, Buss \& Roberts, 2007; Piubelli et al., 2003a; de Souza et al., 2014; Michereff et al., 2011) and is used in breeding programs as a source of resistance (McPherson et al., 2007). This variety was developed by the Agronomic Institute of Campinas in Sao Paulo (Brazil) by crossing breeding lines IAC 78-2318 and IAC-12 (Priolli et al., 2002). Studies on this genotype showed that stink bug attack caused less seed damage and less seed weight loss than other genotypes (Campos et al. 2010). Previous studies found lower adult fresh weight of Nezara viridula when fed on 'IAC-100' and less lipids in females than in those fed on the other genotypes (Piubelli et al., 2003b). However, the mechanisms through which soybean reacts to stink bug attack are still unknown.

Plants respond to herbivore injury through several direct and indirect morphological, biochemical and molecular mechanisms that help them avoid herbivore attack or affect its performance (Fürstenberg-Hägg, Zagrobelny \& Bak, 2013). Direct defense mechanisms affect insect performance and feeding behavior, while indirect defense mechanisms can attract the natural enemies of the herbivores and thus reduce plant loss (War et al., 2012). Insect herbivory induces early responses such us the oxidative burst (production of reactive oxygen species ROS), the expression of defense-related genes, and late responses such as callose deposition and accumulation of proteinase inhibitors (Savatin et al., 2014). Infestation of Vicia faba by $N$. viridula stimulates significantly the production of $\mathrm{H}_{2} \mathrm{O}_{2}$ (Ederli et al., 2017). Moreover, in poplar the concentrations of $\mathrm{H}_{2} \mathrm{O}_{2}$ and malondialdehyde and the activities of ROS-scavenging enzymes, such as superoxide dismutase (SOD), catalase (CAT) and peroxidase (POD), were enhanced by herbivore wounding, suggesting that they are associated with insect resistance. The abovementioned enzymes are related to plant signaling, synthesis of defense compounds, and to oxidative stress tolerance (Bi \& Felton, 1995; Zhang, Hua \& Zhang, 2008; Bednarski et al., 2013; Zebelo \& Maffei, 2014).

After insect attack the activation of defense genes that stimulate the production of the antiherbivory compounds is induced due to internal signals such as calcium ion flow, a phosphorylation cascade and responses mediated by hormones: jasmonic acid (JA) and ethylene (ET) (Waternack, 2007; Howe \& Jander, 2008; Browse, 2009). JA and its methyl ester, methyl jasmonate $(\mathrm{MJ})$, participate in the activation of plant defense mechanisms as signaling compounds in processes related to production of various secondary metabolites (i.e. terpenoids,

Peer] reviewing PDF | (2020:06:49815:1:0:NEW 19 Aug 2020) 
89 phenylpropanoids, and alkaloids) (Wang et al., 2015; Misra et al., 2014). In the case of soybean, 90 isoflavones are the main chemical defense compounds against insects because they affect the 91 performance and survival of the herbivores (Piubelli et al., 2003a). It is well known that MJ and 92 JA induce the accumulation of proteinase inhibitors as direct defense mechanisms against 93 herbivorous insects (Farmer \& Ryan 1990; Farmer, Johnson \& Ryan, 1992). Studies on soybean 94 analyzed the effects of jasmonic acid induction and showed that the soybean looper 95 (Chrysodeixis includens Walker) selects plant leaves that have not been induced by JA 96 (Accamando et al. (2012). In addition, soybean crops grown under conditions of high 97 concentrations of ambient $\mathrm{CO}_{2}$ were unable to express genes related to the JA synthesis, which 98 made them highly susceptible to insect attack (Zavala et al., 2008). The synthesis of jasmonates and many other oxilipins is initiated by lipoxygenases (LOXs), which catalyze dioxygenation of polyunsaturated fatty acids (reviewed by Blee, 2002, Feussner \& Wasternack, 2002, Howe \& Schilmiller, 2002, Wasternack, 2007). LOX activity was higher in soybean plants that were less vulnerable to the attack of $A$. gemmatalis when compared to controls (Fortunato et al. 2007). Since three lipoxygenases, Lox1, Lox2 and Lox3 were detected in soybean seeds (Axelrod, Cheesbrough \& Laakso, 1981), it is possible that seed lipoxygenases regulate defenses against stink bug attack. As a first step to develop a resistant cultivar, it is necessary to identify the sources of resistance for any breeding program (de Morais \& Pinheiro, 2012). Therefore, it is important to determine the different characteristics of the diverse soybean cultivars as regards plant defense against insect attack.

109 The aim of this study is to identify and quantify physical and biochemical soybean defense mechanisms against the southern green stink bug, Nezara viridula attack. Our hypothesis is that herbivory by stink bugs lead to biochemical changes and that there are differences between cultivars at both biochemical and physical level. In this study we have compared soybean seed response to stink bug damage of two cultivars, IAC-100 (resistant) and Davis (susceptible; Orr, Boethel \& Jones, 1985; Kester, Smith \& Gilman 1984). Our results show that there are differences between genotypes as regards the oxidative stress response and isoflavonoid production in response to stink bugs attack. A better understanding of the resistance pathways can help find ways to improve varieties.

\section{Materials \& Methods}

In order to determine soybean resistance to stink bug damage (Nezara viridula L.) in developing seeds, two soybean (Glycine max L.) cultivars, IAC-100 and Davis, were grown under greenhouse conditions and stink bug adults were placed and allowed to feed on pods. Plants were grown with 16:8 L:D light regime at $26 \pm 3^{\circ} \mathrm{C}$, in pots with $3: 1: 1: 1$ soil:peat:sand:perlite mixture. The colony of stink bugs consisted of field-collected individuals from the city of Chacabuco $\left(34^{\circ} 38^{\prime} 00^{\prime \prime} \mathrm{S} 60^{\circ} 28^{\prime} 00^{\prime \prime} \mathrm{O}\right)$ in the province of Buenos Aires (Argentina). The insects were reared at our laboratory (School of Agronomy, University of Buenos Aires) on a diet based on hydrated soybean seeds (cv. Williams) and peeled sunflower seeds, and were then provided water with ascorbic acid (0.5 w/v \%) (Giacometti et. al., 2016).

130

\section{Experimental design}

132 Four experiments were carried out under the same greenhouse conditions in a completely randomized design. In the first experiment, seventeen replications of each cultivar were used, pod hardness was determined by collecting pods at the R6 soybean development stage (Fehr et 
$135 a l ., 1971$ ) and by using a texturometer. In order to determine oxidative stress response of 136 developing seeds to stink bug damage in the second experiment, a single adult stink bug was 137 bagged in on one soybean pod of plants $(\mathrm{n}=5)$ at the R6 development stage (Fehr et al., 1971). 138 Pods of control plants were covered with tulle bags and collected $72 \mathrm{~h}$ after stink bugs started 139 feeding. Soon after, they were fast frozen in liquid nitrogen and stored at $-80^{\circ} \mathrm{C}$ until analysis. In 140 addition, attacked and unattacked pods (one per plant) were collected for $\mathrm{H}_{2} \mathrm{O}_{2}$ detection in 141 developing seeds. Five replications of each cultivar were used for stink bug infestation with an 142 equal number of control plants. In the third experiment undamaged and damaged seeds by stink 143 bugs were collected to determine isoflavonoid accumulation after 72-hr herbivory. Finally, a 144 fourth experiment was performed to determine the LOX expression level in damaged and undamaged seeds, and pods were collected 24-hr after herbivory and were fast frozen in liquid nitrogen.

\section{Hardness determination on pods}

Hardness, the peak force required to penetrate a soybean pod, was measured with an INSTRON 4442 tensile tester calibrated to penetrate $12 \mathrm{~mm}$ at a rate of $2.0 \mathrm{~mm} \mathrm{sec}^{-1}$ with a needle. The tests were performed on both soybean cultivars at the R6 phenological stage and the needle was inserted in pods at the second seed position. Results were expressed as gram-force per square centimeter $\left(\mathrm{gf} \mathrm{cm}^{2}\right)$ and represented the maximum force required to penetrate a pod with the tip needle in order to simulate the situation in which the sting bugs insert the stylus (de Santana Souza et al., 2013).

\section{Oxidative stress response}

Extracts for determination of catalase (CAT), superoxide dismutase (SOD) and Guaiacol peroxidase (GPOX) activities were prepared from $0.3 \mathrm{~g}$ of soybean seeds homogenized under ice-cold conditions in $3 \mathrm{~mL}$ of extraction buffer, containing $50 \mathrm{mM}$ phosphate buffer $(\mathrm{pH} 7.4)$, $1 \mathrm{mMEDTA}, 1 \mathrm{~g}$ PVP, and $0.5 \%(\mathrm{v} / \mathrm{v})$ Triton $\mathrm{X}-100$ at $4^{\circ} \mathrm{C}$. The homogenates were centrifuged at $10000 \times \mathrm{g}$ for 20 minutes and the supernatant fraction was used for the assays. Total protein content was determined by following the Bradford method for protein quantification (1976).

CAT activity was determined according to a modified protocol of Chance, Sies \& Boveris (1979). The reaction was conducted in a quartz cuvette by measuring the decrease in absorption at $240 \mathrm{~nm}$ in a reaction medium containing $150 \mu \mathrm{L}$ of enzyme extract, $50 \mathrm{mM}$ potassium phosphate buffer ( $\mathrm{pH}$ 7.2) and $2 \mathrm{mM} \mathrm{H}_{2} \mathrm{O}_{2}$ for 2 minutes. CAT activity was determined using the molar absorptivity of $\mathrm{H}_{2} \mathrm{O}_{2}$ at $240 \mathrm{~nm}$ and expressed as $\mu$ moles mg protein ${ }^{-1} \mathrm{~min}^{-1}$.

SOD activity was assayed by the inhibition of the photochemical reduction of NBT (Becana et al., 1986). The reaction mixture consisted of 50, 100 and $200 \mu \mathrm{L}$ of enzyme extract and $3.5 \mathrm{~mL}$ $\mathrm{O}_{2} \bullet-$ generating solution which contained $14.3 \mathrm{mM}$ methionine, $82.5 \mu \mathrm{M} \mathrm{NBT}$, and $2.2 \mu \mathrm{M}$ riboflavin. Extracts were brought to a final volume of $0.3 \mathrm{~mL}$ with $50 \mathrm{mM} \mathrm{K}$-phosphate $(\mathrm{pH} 7.8)$ and $0.1 \mathrm{mM} \mathrm{Na}_{2}$ EDTA.

Sample tubes were shaken and placed in front of fluorescent lamps during 10 minutes. The reduction in NBT was followed by reading absorbance at $560 \mathrm{~nm}$. Blanks and controls were run in the same way but without illumination and enzyme, respectively. One unit of SOD was defined as the amount of enzyme which produced a 50\% inhibition of NBT reduction under the assay conditions.

GPOX activity was determined according to the protocol devised by Shannon et al. (1966) which consists in measuring the increase in absorption at $470 \mathrm{~nm}$ due to the formation of tetraguaiacol 
181

182

183

184

185

186

187

188

189

190

191

192

193

194

195

196

197

198

199

200

201

202

203

204

205

206

207

208

209

210

211

212

213

214

215

216

217

218

219

220

221

222

223

224

225 at $30^{\circ} \mathrm{C}$ in a reaction extract, $50 \mathrm{mM}$ buffer K-phosphate $50 \mathrm{mM}, \mathrm{pH} 7,0.1 \mathrm{mM}$ EDTA, $10 \mathrm{mM}$ guaiacol and $10 \mathrm{mM} \mathrm{H}_{2} \mathrm{O}_{2}$. One unit of POD forms $1 \mu \mathrm{mol}$ of guaiacol oxidised per min under assay conditions.

\section{Detection of $\mathrm{H}_{2} \mathrm{O}_{2}$}

To visually analyze $\mathrm{H}_{2} \mathrm{O}_{2}$ generation, stink bug damaged seeds and their respective controls were excised and immersed in a 1\% solution of 3,3-Diaminobenzidine (DAB) for $24 \mathrm{~h}$ under light at $25{ }^{\circ} \mathrm{C}$ (Zilli et al., 2008). DAB generates a reddish-brown compound that could be detected at the site of $\mathrm{H}_{2} \mathrm{O}_{2}$ formation in the presence of endogenous peroxidase activity. After staining, formation of brown precipitates was documented by photography.

\section{Lipoxygenase expression}

The expression level of Lipoxygenase 1 ( $L O X 1)$ and Lipoxygenase 2 ( $L O X 2)$ genes in soybean seeds was determined. Briefly, total RNA was isolated using the RNeasy Plant Mini kit (QIAGEN Inc., Valencia, CA, USA) according to the manufacturer's protocol. RNA concentration was determined with a fluorometer QubitTM (Invitrogen), and quality and quantity were assessed spectrophotometrically before the cDNA was synthesized using the Thermo Scientific RevertAid Reverse Transcriptase in a Bio-Rad My CyclerTM Termal Cycler.

An ABI 7500 Fast Real-Time PCR system was used to perform the qRT-PCR (Applied Biosystems, Foster City, CA, USA) with the SYBR Green Real-time Master Mix. The LOX1 and $L O X 2$ primer sequences in this study are detailed in Table 1. The housekeeping soybean elongation factor $(E L F 1 b)$ was used as a reference gene for relative quantification and the target expression relative to the housekeeping was used for ANOVA.

\section{Isoflavonoid determination}

Isoflavonoid accumulation was determined after $72 \mathrm{~h}$ of herbivory treatment in seeds at R6 according to Fehr et al (1971), the lipid phase of seeds was removed with cyclohexane (Zavala et al., 2015). $0.2 \mathrm{~g}$ of pulverized seeds were placed in a $50 \mathrm{ml}$ tube and mixed with $10 \mathrm{~mL}$ of cyclohexane and incubated for 6 hours. Then, tubes were centrifuged at $1500 \mathrm{rpm}$ for 10 minutes. Supernatant was discarded and the pellet was used for the extraction step. Isoflavonoids were extracted with methanol plus rutin that was used as an extraction internal control $(0.1 \mathrm{~g} / 5$ $\mathrm{ml} \mathrm{MeOH}$ ). $10 \mathrm{~mL}$ of methanol were added to $50 \mathrm{~mL}$ tubes and incubated for 6 hours at room temperature. Then tubes were centrifuged at $1500 \mathrm{rpm}$ for 10 minutes. Supernatant was saved. The solvent was then evaporated at $40{ }^{\circ} \mathrm{C}$ and samples were re-dissolved with $500 \mu \mathrm{L}$ of $\mathrm{MeOH}$. Samples were purified with a C18 Silica Cartridge (Agilent Technologies, Palo Alto, CA, USA) using different mixtures of $\mathrm{MeOH}-\mathrm{H} 2 \mathrm{O}$. Aliquots of $5 \mu \mathrm{L}$ were subjected to high-performance liquid chromatography (HPLC; Agilent 1100 A series) using a reverse-phase octadesyl column (Eclipse XDB-C18 $4.6 \times 150 \mathrm{~mm}, 5 \mu \mathrm{m}$ ). Isoflavonoids were eluted using a mobile phase gradient of $15-60 \%$ acetonitrile in $0.1 \%$ acetic acid for $60 \mathrm{~min}$ at a flow rate of $1 \mathrm{~mL} \mathrm{~min}-1$. Compounds were measured with the detector set at $\lambda 270 \mathrm{~nm}$. Retention times and quantitative data for daidzin, daidzein, genistin and genistein were obtained by comparison to known standards (all from Sigma-Aldrich, St. Louis, MO, USA). External standard curves were performed for isoflavonoid quantification.

Statistical analysis

Peer) reviewing PDF | (2020:06:49815:1:0:NEW 19 Aug 2020) 
226 The experiments were set up as a completely randomized design with factorial treatments. One 227 factor was the genotype (IAC-100 and Davis) and the second was insect damage (control and 228 treated). Data were analyzed with the Infostat v. 2011 statistical package (Di Rienzo et al., 229 2011). Hardness analysis of pods, and SOD, CAT and GPOX activities as well as seed 230 isoflavonoid contents in each experiment were analyzed using analysis of variance (ANOVA). 231 Data on isoflavonoid content were transformed as needed to meet the assumptions of ANOVA 232 by square root transformation. We applied the Tukey pairwise multiple comparisons procedure 233 for studying GENOTYPE and TREATMENT effects.

234 Hierarchical clustering of oxidative stress enzymes was performed with the same data used for 235

236

237

238

239

240

241

242

243

244

245

246

247

248

249

250

251

252

253

254

255

256

257

258

259

260

261

262

263

264

265

266

267

268

269

270

271

\section{Results}

\section{Damage and hardness assessment of pods}

Oxidative damage caused by stink bugs was observed by visual analyses of $\mathrm{H}_{2} \mathrm{O}_{2}$ generation. Davis seeds affected by Nezara viridula exhibited highly enhanced brownish staining compared to the IAC-100 genotype (Figure 1). Textural analysis of pods showed that IAC-100 has greater resistance to penetration than Davis ( $p<0.05$; Figure 2). This can be a physical barrier to the insect's stylet penetration.

\section{Stress metabolism}

According to our results, the cluster analysis of oxidative stress enzyme activities (CAT, SOD, GPOX) that was carried out using the statistical package Infostat v. 2011 (Di Rienzo et al., 2011) showed two main clusters that grouped the genotypes with the treatments. Figure 3 A shows one cluster containing IAC-100 treated with stink bugs, and the second cluster containing IAC-100 control, Davis treated and Davis control. When exposed to insect treatment, the cluster distribution suggests a differential induction of enzyme activities between the resistant and susceptible genotypes. In addition, there is no Genotype $\mathrm{x}$ Treatment interaction in CAT activity and the differences are due to Genotype and Treatment ( $\mathrm{p}<0.05$; Figure $3 \mathrm{~B}$ ). Although the CAT enzyme is induced in both genotypes, its activity is always higher in IAC-100 than in Davis. SOD activity was significantly greater in IAC-100 $(\mathrm{p}<0.05)$ when affected by stink bugs (Figure $3 \mathrm{C}$ ). When comparing cultivars, GPOX showed a higher activity in IAC-100 both with and without damage caused by the insect $(p<0.05$, Figure $3 \mathrm{D})$.

\section{Lipoxygenase expression quantification}

Expression of $L O X 1$ and $L O X 2$ was induced by herbivory in both soybean cultivars when compared to their respective controls (Fig 4). It suggests that soybean plants respond to this type of stress by increasing $L O X$ expression after $24 \mathrm{~h}$ following treatment $(\mathrm{p}<0.05)$.

\section{Isoflavonoids}

Concentrations of isoflavonoids in soybean seeds showed differences between cultivars and types of compounds (Figure 5). After herbivory, the concentration of daidzin and genistin increased in both genotypes and constitutive concentrations were similar and very low $(p<0.05$; Figure $5 \mathrm{~A}$ and $\mathrm{C}$ ). Higher levels of daidzein were found in the IAC-100 genotype, regardless of the treatment, with a strong uprising trend under herbivory $(p<0.05$; Figure $5 \mathrm{~B})$. Except for one repeat of the cultivar Davis genistein was not detected in any treatment (supplementary information). 


\section{Discussion}

274 Previous experiments with the IAC-100 soybean genotype reported low incidence of stink bugs

275 (McPherson et al., 2007). This cultivar has PI 229358 (Clement \& Quisenberry, 1998) and PI

276274454 (Souza et al., 2015) in its genealogy (Carrao-Panizzi \& Kitamura 1995), which exhibits a

277 high degree of resistance to the stink bug complex. Some studies have shown antixenosis in IAC-

278100 against $N$. viridula, P. guildinii and E. heros (Campos et al., 2010; Silva et al., 2014 and de

279 Souza et al., 2014), and biological effects through isoflavonoids on N. viridula (Piubelli et al.,

280 2003a). Our study suggests that cultivar IAC-100 maybe more tolerant to the southern green

281 stinkbug due to greater hardness in pods, which serves as the first line of defense. In addition, a

282 higher antioxidative enzyme activity was involved in plant defense, and it showed high levels of

283 isoflavonoids in response to insect attack which, according to some authors (Lane et al., 1985;

284 Murakami et al., 2014; Simmonds \& Stevenson, 2001) affect the performance and survival of the

285 herbivores.

286 Antixenosis in resistant plants can be related to morphological factors such as thickened plant epidermal layers, waxy deposits on leaves, stems, or fruits, nutritional deficiency, and chemical compounds (Smith, 2005). The thickness of various plant tissues influences the degree of resistance in some crop cultivars. Stink bug ( $N$. viridula) damage elicits activation of MAPK signal in soybean seeds and induced salicylic acid that induced genes related with cell wall restructuration and increased lignin content, which can increase resistance to new insect attack by hardening cell walls (Giacometti et al., 2018). In this study, pods of IAC-100 cultivar showed greater resistance to penetration when compared to those of Davis, suggesting that hardening may be a physical barrier to insect feeding (Figure 2).

295 Under stress conditions in plants, such as insect feeding, many signaling pathways are activated 296 by different types of ROS causing "oxidative burst" (Maffei, Mithöfer \& Boland, 2007). After insect attack, ROS are accumulated acting as the first barrier against the attack of pathogens and herbivores. However, to avoid self-toxicity by ROS, plant cells have ROS scavenging systems that help to remove the excess concentration and maintain a relatively low and constant one (War et al., 2012). Tolerance in plants is generally related to the control capacity of the cellular redox state resulting in lower oxidative damage (Slesak et al. 2007). ROS accumulation was detected after the feeding period of the chewing caterpillar $S$. littoralis or the piercing-sucking action of the spider mite Tetranychus urticae (Maffei et al., 2006; Afify et al., 2011). Infestation of lima beans by $S$. littoralis revealed, trough diaminobenzidine (DAB) staining, accumulation of $\mathrm{H}_{2} \mathrm{O}_{2}$ around the wounded area (Maffei et al., 2006). In our study we found that IAC-100 had less accumulation of $\mathrm{H}_{2} \mathrm{O}_{2}$ after insect feeding when compared to the susceptible genotype, which suggests that it has a higher capacity to control the redox state. A previous study demonstrated that ROS detoxification enzymes were only induced in $\mathrm{H}_{2} \mathrm{O}_{2}$-accumulating resistant lines (Moloi $\&$ van der Westhuizen 2008). POD is one of such group of antioxidative enzymes, which scavenges the ROS besides having other defensive roles because they are also an important component of the immediate response of plants to insect damage (War et al., 2012). Catalases remove the $\mathrm{H}_{2} \mathrm{O}_{2}$ and reduce $\mathrm{H}_{2} \mathrm{O}_{2}$ to $2 \mathrm{H}_{2} \mathrm{O}$. And SOD constitutes a frontline in the defense against ROS as they catalyze the dismutation of $\mathrm{O}_{2}^{-}$. (superoxide radical) to $\mathrm{H}_{2} \mathrm{O}_{2}$ (Caverzan, Casassola \& Brammer, 2016). In wheat, an increase in SOD transcript in response to differential 315 heat shock treatment was related to an enhanced tolerance to environmental stresses (Kumar et 316 al., 2013). The present study demonstrates that the resistant cultivar had more control of the 
317 cellular redox state given its high level of enzyme activity after herbivory in SOD, GPOX y CAT 318 (Figure 3).

319 Many studies have shown that LOXs are implicated in the defense systems of several plant species against pathogens and insects (Koch et al., 1992; Melan et al., 1993; Felton et al., 1994; Christensen et al., 2013). Induction of LOX activity after herbivory has previously been studied in tomato in response to Helicoverpa armigera (Yan et al., 2013), in Arabidopsis following infestation by Myzus persicae and in lima bean in response to Tetranychus urticae (Moran \& Thompson, 2001; Arimura et al., 2000). In developing seeds of soybean, we found an induction of $L O X 1$ and $L O X 2$ after herbivory in both genotypes under study suggesting that this pathway is activated in response to the damage caused by Nezara viridula. LOX activity regulates the production of the hormone JA, which modulates flavonoids and isoflavonoids that protect plants against insect pests and affect the behavior, growth and development of insects (Simmonds, 2003). In Arabidopsis, resistance against Spodoptera frugiperda is enhanced overexpressing a transcription factor that controls flavonoid production (Johnson \& Dowd, 2004). In soybean leaves, flavonoids negatively affected the behavior of Aphis glycines and Trichoplusia ni (Meng et al., 2011; Neupane \& Norris 1990). Moreover, soybean seed damage caused by soybean pod borer (Leguminivora glycinivorella) was negatively correlated with higher levels of isoflavonoids, and showed positive correlations between isoflavonoid content in pods and undamaged seeds in treatments with stink bugs (Nezara viridula and Piezodorus guildinii) (Zhao et al., 2015; Zavala et al., 2015). Our results reveal that stink bug herbivory differentially promoted isoflavonoid production between genotypes with variations according to the type of compound. It can thus be concluded that not only total production of isoflavonoids but also the type of isoflavonoid produced can affect insect behavior.

\section{Conclusions}

Taken the results together, it can be inferred that stink bug herbivory injury generates cell wall changes, induces pathways related to oxidative stress and secondary metabolites in developing seeds of soybean. As a result of the resistance characteristics to insects, such as control of cellular redox state and production of secondary metabolites, IAC-100 is a promising cultivar for a breeding program. However, further studies are still required to understand the functions of genes and the regulatory factors involved in defense responses in order to develop molecular markers for a breeding program.

350

351 The study of host plant resistance is an important alternative for producers in Argentina, but even more in Brazil, not only because of the high insect pressure but also for the phytopathogenic fungi that lead to the frequent use of chemical control.

353

354

355

\section{Acknowledgements}

GDM Seeds for the availability for the use of greenhouses and other infrastructure. Verónica Feuring and Alina Crelier for technical assistance. Romina Giacometti and Natalia Ilina for the help in molecular biology methods.

\section{References}

360

361

362

Accamando AK, Cronin JT. (2012). Costs and benefits of jasmonic acid-induced responses in soybean. Environmental entomology, 41(3), 551-561 
363

364

365

366

367

368

369

370

371

372

373

374

375

376

377

378

379

380

381

382

383

384

385

386

387

388

389

390

391

392

393

394

395

396

397

398

399

400

401

402

403

404

405

406

407

Afify AEMM, El-Beltagi HS, Fayed SA, Shalaby EA (2011). Acaricidal activity of different extracts from Syzygiumcumini L. Skeels (Pomposia) against Tetranychus urticae Koch. Asian Pacific journal of tropical biomedicine, 1(5), 359-364.

Arimura GI, Ozawa R, Shimoda T, Nishioka T, Boland W, Takabayashi, J (2000). Herbivoryinduced volatiles elicit defense genes in lima bean leaves. Nature, 406(6795), 512-515.

Axelrod B, Cheesbrough TM, Laakso S (1981). Lipoxygenase from soybeans: EC 1.13. 11.12 Linoleate: oxygen oxidoreductase. In Methods in Enzymology (Vol. 71, pp. 441-451). Academic Press.

Becana M, Aparicio-Tejo P, Irigoyen JJ, Sanchez-Diaz M (1986). Some enzymes of hydrogen peroxide metabolism in leaves and root nodules of Medicago sativa. Plant Physiology, 82(4), 1169-1171.

Blee E (2002). Impact of phyto-oxylipins in plant defense. Trends Plant Sci 7, 315-321.

Bi J.L., Felton G.W. (1995). Foliar oxidative stress and insect herbivory: primary compounds, secondary metabolites, and reactive oxygen species as components of induced resistance. Journal of Chemical Ecology, 21(10), 1511-1530.

Bradford MM (1976). A rapid and sensitive method for the quantitation of microgram quantities of protein utilizing the principle of protein-dye binding. Analytical biochemistry, 72(1-2), 248254.

Bednarski W, Borowiak-Sobkowiak B, Wilkaniec B, Samardakiewicz S, Morkunas I (2013). Oxidative stress in pea seedling leaves in response to Acyrthosiphon pisum infestation. Phytochemistry, 93, 49-62.

Boerma HR, Walker DR (2005). Discovery and utilization of QTLs for insect resistance in soybean. Genetica. 123, 181-189.

Browse J (2009). Jasmonate passes muster: a receptor and targets for the defense hormone. Annu Rev Plant Biol 60, 183-205.

Campos M, Knutson A, Heitholt J, Campos C (2010). Resistance to seed feeding by southern green stink bug, Nezara viridula (Linnaeus), in soybean, Glycine max (L.) Merrill. Southwestern Entomologist, 35(3), 233-239.

Carrao-Panizzi MC, Kitamura K (1995). Isoflavone content in Brazilian soybean cultivars. Japanese Journal of Breeding, 45(3), 295-300.

Caverzan A, Casassola A, Brammer SP (2016). Antioxidant responses of wheat plants under stress. Genetics and molecular biology, 39(1), 1-6. 
408 Chance B, Sies H, Boveris A (1979). Hydroperoxide metabolism in mammalian

409 organs. Physiological reviews, 59(3), 527-605.

410

411

412

413

414

415

416

417

418

419

420

421

422

423

424

425

426

427

428

429

430

431

432

433

434

435

436

437

438

439

440

441

442

443

444

445

446

447

448

449

450

451

452

Chen H, Wang FW, Dong YY, Wang N, Sun YP, Li XY, Liu L, Fan XD, Yin HL, Jing YY, Zhang XY, Li YL, Chen G, Li HY (2012). Sequence mining and transcript profiling to explore differentially expressed genes associated with lipid biosynthesis during soybean seed development. BMC plant biology, 12(1), 122.

Christensen SA, Nemchenko A, Borrego E, Murray I, Sobhy IS, Bosak L, De Blasio S, Erb M, Robert CAM, Vaughn K A, Herrfurth C, Tumlinson J, Feussner I, Jackson D, Turlings TCJ, Engelberth J, Nansen C, Meeley R, Kolomiets MV (2013). The maize lipoxygenase, ZmLOX10, mediates green leaf volatile, jasmonate and herbivore-induced plant volatile production for defense against insect attack. The Plant Journal, 74(1), 59-73.

Clement SL, Quisenberry SS (1998). Global plant genetic resources for insect-resistant crops. CRC Press.

Corrêa-Ferreira, B. S., Moscardi, F. (1996). Biological control of soybean stink bugs by inoculative releases of Trissolcus basalis. Entomologia experimentalis et applicata, 79(1), 1-7.

de Morais AA, Pinheiro JB (2012). Breeding for Resistance to Insect Pests. In Plant Breeding for Biotic Stress Resistance (pp. 103-125). Springer Berlin Heidelberg.

de Santana Souza E, Lopes Baldin EL, da Silva GF, Paulo J, Lourenção AL (2013). Feeding preference of Nezara viridula (Hemiptera: Pentatomidae) and attractiveness of soybean genotypes. Chilean jornal of agricultural research, 73(4), 351-357.

de Souza PV, Machado BR, da Silva DC, Menezes IPP, Araújo MS, de Jesus FG (2014). Effect of resistance and trichome inducers on attraction of Euschistus heros (Hemiptera: Pentatomidae) to soybeans. African Journal of Agricultural Research, 9(10), 889-894.

Di Rienzo JA, Casanoves F, Balzarini MG, Gonzalez L, Tablada M, Robledo CW (2011) InfoStat, Statistical Software version 2011. Universidad Nacional de Córdoba Argentina.

Ederli L, Brunetti C, Centritto M, Colazza S, Frati F, Loreto F, Marino G, Salerno G, Pasqualini S (2017). Infestation of broad bean (Vicia faba) by the green stink bug (Nezara viridula) decreases shoot abscisic acid contents under well-watered and drought conditions. Frontiers in plant science, 8, 959.

Farmer EE, Johnson RR, Ryan CA (1992). Regulation of expression of proteinase inhibitor genes by methyl jasmonate and jasmonic acid. Plant Physiology 98, 995-1002.

Farmer EE, Ryan CA (1990). Interplant communication: airborne methyl jasmonate induces synthesis of proteinase inhibitors in plant leaves. Proc Natl Acad Sci, 87, 7713-7716.

Peer) reviewing PDF | (2020:06:49815:1:0:NEW 19 Aug 2020) 
453 Fehr WR, Caviness CE, Burmood DT, Pennington JS (1971). Stage of development descriptions

454 for soybeans, Glycine max (L.) Merrill. Crop Science 11,929-931.

455

456

457

458

459

460

461

462

463

464

465

466

467

468

469

470

471

472

473

474

475

476

477

478

479

480

481

482

483

484

485

486

487

488

489

490

491

492

493

494

495

496

Felton GW, Bi JL, Summers CB, Mueller AJ, Duffey SS (1994). Potential role of lipoxygenases in defense against insect herbivory. Journal of Chemical Ecology, 20(3), 651-666.

Feussner I., Wasternack, C. (2002). The lipoxygenase pathway. Annu Rev Plant Biol 53, 275297.

Freeman BC, Beattie GA (2008). An Overview of Plant Defenses against Pathogens and Herbivores. The Plant Health Instructor. DOI: 10.1094/PHI-I-2008-0226-01

Fortunato FS, Oliveira MGA, Brumado MHN, Silva CHO, Guedes RNC, Moreira MA (2007). Lipoxygenase-induced defense of soybean varieties to the attack of the velvetbean caterpillar (Anticarsia gemmatalisHubner). Journal of Pest Science, 80, 241-247.

Fürstenberg-Hägg J, Zagrobelny M, Bak S (2013). Plant defense against insect herbivores. International journal of molecular sciences, 14(5), 10242-10297.

Giacometti R, Barneto J, Barriga LG, Sardoy PM, Balestrasse K, Andrade AM, Pagano EA, Alemano SG, Zavala JA (2016). Early perception of stink bug damage in developing seeds of field-grown soybean induces chemical defenses and reduces bug attack. Pest management science. 72: 1585-1594

Giacometti R, Illina N, Pagano EA, Zavala JA (2018). Stink bug nezara viridula sustains late MAPKs phosphorylation status and induces expression of genes related with cell wall rearrangement in developing soybean seeds. Arthropod-Plant Interactions. 12: 531-541.

Howe G, Schilmiller AL (2002). Oxylipin metabolism in response to stress. Curr Opin Plant Biol 5, 230-236.

Howe G, Jander G (2008). Plant immunity to insect herbivores. Annual Review of Plant Biology, $59,41-66$.

Jensen RL, Newsom LD (1972). Effect of stink-bug-damaged soybean seeds on germination, emergence and yield. Journal of Economic Entomology, 65, 261-264.

Jian B, Liu B, Bi YR, Hou WS, Wu CX, Han TF (2008) Validation of internal control for gene expression study in soybean by quantitative real-time PCR. BMC Mol Biol 9:59. doi: 10.1186/1471-2199-9-59.

Johnson ET, Dowd PF (2004). Differentially enhanced insect resistance, at a cost, in Arabidopsis thaliana constitutively expressing a transcription factor of defensive metabolites. Journal of agricultural and food chemistry, 52(16), 5135-5138. 
497 Kester K M, Smith CM, Gilman DF (1984). Mechanisms of resistance in soybean (Glycine max 498 [L.] Merrill) genotype PI171444 to the southern green stink bug, Nezara viridula (L.) 499 (Hemiptera: Pentatomidae). Environmental entomology, 13(5), 1208-1215.

500

501

502

503

504

505

506

507

508

509

510

511

512

513

514

515

516

517

518

519

520

521

522

523

524

525

526

527

528

529

530

531

532

533

534

535

536

537

538

539

540

541
Koch E, Meier BM, Eiben HG, Slusarenko A (1992). A lipoxygenase from leaves of tomato (Lycopersicon esculentum Mill.) is induced in response to plant pathogenic pseudomonads. Plant Physiology, 99(2), 571-576.

Kumar RR, Sharma SK, Goswami S, Singh K, Gadpayl KA, Singh GP, Pathak H, Rai RD (2013). Transcript profiling and biochemical characterization of mitochondrial superoxide dismutase (mtSOD) in wheat (Triticum aestivum) under different exogenous stresses. Australian Journal of Crop Science, 7(3), 414.

Lane GA, Biggs DR, Russell GB, Sutherland OR, Williams EM, Maindonald JH, Donnell DJ (1985). Isoflavonoid feeding deterrents for Costelytra zealandica Structure-Activity relationships. Journal of chemical ecology, 11(12), 1713-1735.

Maffei ME, Mithöfer A, Boland W (2007). Insects feeding on plants: rapid signals and responses preceding the induction of phytochemical release. Phytochemistry, 68(22), 2946-2959.

Maffei ME, Mithöfer A, Arimura GI, Uchtenhagen H, Bossi S, Bertea CM, Starvaggi Cucuzza L, Novero M, Volpe, V, Quadro S, Boland W (2006). Effects of feeding Spodoptera littoralis on lima bean leaves. III. Membrane depolarization and involvement of hydrogen peroxide. Plant Physiology, 140(3), 1022-1035.

McPherson RM, Buss GR, Roberts PM (2007). Assessing stink bug resistance in soybean breeding lines containing genes from germplasm IAC-100. Journal of Economic Entomology. Journal of economic entomology, 100(4), 1456-1463.

Melan MA, Dong X, Endara ME, Davis KR, Ausubel FM, Peterman TK (1993). An Arabidopsis thaliana lipoxygenase gene can be induced by pathogens, abscisic acid, and methyl jasmonate. Plant Physiology, 101(2), 441-450.

Meng F, Han Y, Teng W, Li Y, Li W (2011). QTL underlying the resistance to soybean aphid (Aphis glycines Matsumura) through isoflavone-mediated antibiosis in soybean cultivar 'Zhongdou 27'. Theoretical and applied genetics, 123(8), 1459-1465.

Michereff MFF, Laumann RA, Borges M, Michereff-Filho M, Diniz I R, Neto ALF, Moraes MCB (2011). Volatiles mediating a plant-herbivore-natural enemy interaction in resistant and susceptible soybean cultivars. Journal of chemical ecology, 37(3), 273-285.

Misra RC, Maiti P, Chanotiya CS, Shanker K, Ghosh S (2014). Methyl jasmonate-elicited transcriptional responses and pentacyclic triterpene biosynthesis in sweet basil. Plant physiology, 164(2), 1028-1044. 
542 Moloi MJ, van der Westhuizen AJ (2008). Antioxidantive responses and the Russian wheat 543 aphid (Diuraphisnoxia) resistance responses in wheat (Triticum aestivum). Plant Biology 10, $544 \quad 403-407$.

545

546 Moran PJ, Thompson G A (2001). Molecular responses to aphid feeding in Arabidopsis in 547 548

\begin{abstract}
relation to plant defense pathways. Plant Physiology, 125(2), 1074-1085.
\end{abstract}
Murakami S, Nakata R, Aboshi T, Yoshinaga N, Teraishi M, Okumoto Y, Ishihara A, Morisaka H, Huffaker A, Schmelz E A, Mori, N (2014). Insect-induced daidzein, formononetin and their conjugates in soybean leaves. Metabolites, 4(3), 532-546.

Neupane FP, Norris DM (1990). Iodoacetic acid alteration of soybean resistance to the cabbage looper (Lepidoptera: Noctuidae). Environmental entomology, 19(2), 215-221.

Orr DB, Boethel D J, Jones WA (1985). Biology of Telenomuschloropus (Hymenoptera: Scelionidae) from eggs of Nezara viridula (Hemiptera: Pentatomidae) reared on resistant and susceptible soybean genotypes. The Canadian Entomologist, 117(09), 1137-1142.

Piubelli GC, Hoffmann-Campo CB, De Arruda IC, Franchini JC, Lara FM (2003a). Flavonoid increase in soybean as a response to Nezara viridula injury and its effect on insect-feeding preference. Journal of chemical ecology, 29(5), 1223-1233.

Piubelli GC, Hoffmann-Campo CB, Arruda ICD, Lara FM (2003b). Nymphal development, lipid content, growth and weight gain of Nezara viridula (L.) (Heteroptera: Pentatomidae) fed on soybean genotypes. Neotropical Entomology, 32(1), 127-132.

Priolli RHG, Mendes-Junior CT, Arantes NE, Contel EPB (2002). Characterization of Brazilian soybean cultivars using microsatellite markers. Genetics and Molecular Biology, 25(2), 185-193.

Shannon LM, KayE, Lew JY (1966). Peroxidase isozymes from horseradish roots I. Isolation and physical properties. Journal of Biological Chemistry, 241(9), 2166-2172.

Savatin DV, Gramegna G, Modesti V, Cervone F (2014). Wounding in the plant tissue: the defense of a dangerous passage. Frontiers in plant science, 5(470):470.

Schaefer, C. W., Panizzi, A. R. (Eds.). (2000). Heteroptera of economic importance. CRC press

Silva JP, Baldin EL, Canassa VF, Souza ES, Lourenção AL (2014). Assessing antixenosis of soybean entries against Piezodorus guildinii (Hemiptera: Pentatomidae). Arthropod-Plant Interactions, 8(4), 349-359.

Simmonds M S (2003). Flavonoid-insect interactions: recent advances in our knowledge. Phytochemistry, 64(1), 21-30.

Simmonds M S, Stevenson P C (2001). Effects of isoflavonoids from Cicer on larvae of Heliocoverpa armigera. Journal of chemical ecology, 27(5), 965-977. 
588

589

590

591

592

593

594

595

596

597

598

599

600

601

602

603

604

605

606

607

608

609

610

611

612

613

614

615

616

617

618

619

620

621

622

623

624

625

626

627

628

629

630

631

632

633

Slesak I, Libik M, Karpinska B, Karpinski S, Miszalski Z (2007). The role of hydrogen peroxide in regulation of plant metabolism and cellular signaling in response to environmental stresses. Acta Biochimica Polonica-English Edition, 54(1), 39.

Smith CM (2005). Plant resistance to arthropods: Molecular and conventional approaches, Dordrecht, The Netherlands: Springer.

Souza ES, Silva JPGF, Baldin ELL, Pierozzi CG, Cunha LS, Canassa VF, Pannuti LER, Lourenção AL (2015). Response of soybean genotypes challenged by a stink bug complex (Hemiptera: Pentatomidae). Journal of economic entomology, 109(2), 898-906.

Wang J, Qian J, Yao L, Lu Y (2015). Enhanced production of flavonoids by methyl jasmonate elicitation in cell suspension culture of Hypericum perforatum. Bioresources and Bioprocessing, 2(1), 5.

War AR, Paulraj MG, Ahmad, T, Buhroo AA, Hussain B, Ignacimuthu S, Sharma H C (2012). Mechanisms of plant defense against insect herbivores. Plant signaling and behavior, 7(10), 1306-1320.

Wasternack C (2007). Jasmonates: an update on biosynthesis, signal transduction and action in plant stress response, growth and development. Ann Bot. 100(4), 681-97.

Yan L, Zhai Q, Wei J, Li S, Wang B, Huang T, Du M, Sun J, Kang L, Li CB, Li, C (2013). Role of tomato lipoxygenase $\mathrm{D}$ in wound-induced jasmonate biosynthesis and plant immunity to insect herbivores. PLoS genetics, 9(12), e1003964.

Zavala JA, Mazza CA, Dillon FM, Chludil HD, Ballare CL (2015). Soybean resistance to stink bugs (Nezara viridula and Piezodorus guildinii) increases with exposure to solar UV-B radiation and correlates with isoflavonoid content in pods under field conditions. Plant, cell and environment,38 (5), 920-928.

Zavala J, Barneto J, Barriga L, Pagano E (2010). Plant-Insect Interactions in Soybean Crops: Plant Responses to Stink Bugs. 1st Latin American Meeting of Chemical Ecology (p. 82). Colonia del Sacramento: Latin American Association of Chemical Ecology.

Zavala JA, Casteel CL, De Lucia EH, Berenbaum MR (2008). Anthropogenic increase in carbon dioxide compromises plant defense against invasive insects. Proceedings of the national academy of sciences, 105(13), 5129-5133.

Zebelo SA, Maffei ME (2014). Role of early signalling events in plant-insect interactions. Journal of Experimental Botany, 66(2), 435-448.

Zhang SZ, Hua BZ, Zhang F (2008). Induction of the activities of antioxidative enzymes and the levels of malondialdehyde in cucumber seedlings as a consequence of Bemisiatabaci (Hemiptera: Aleyrodidae) infestation. Arthropod-Plant Interactions, 2(4), 209-213.

Peer) reviewing PDF | (2020:06:49815:1:0:NEW 19 Aug 2020) 
634

635 Zhao G, Jiang Z, Li D, Han Y, Hu H, Wu L, Wang Y, Gao Y, Teng W, Li Y, Zeng G, Meng F, 636 Zeng, G Meng F, Li W (2015). Molecular loci associated with seed isoflavone content may 637 underlie resistance to soybean pod borer (Leguminivora glycinivorella). Plant Breeding, 134(1), $63878-84$.

639

640 Zilli CG, Balestrasse KB, Yannarelli GG, Polizio AH, Santa-Cruz, DM, Tomaro ML (2008). 641 Heme oxygenase up-regulation under salt stress protects nitrogen metabolism in nodules of 642 soybean plants. Environmental and experimental botany, 64(1), 83-89. 
Figure 1

$\mathrm{H}_{2} \mathrm{O}_{2}$ generation in sites damaged by stink bug.

Brown color shows a more affected condition. Images were acquired with a digital camera Nikon Coolpix L110. 


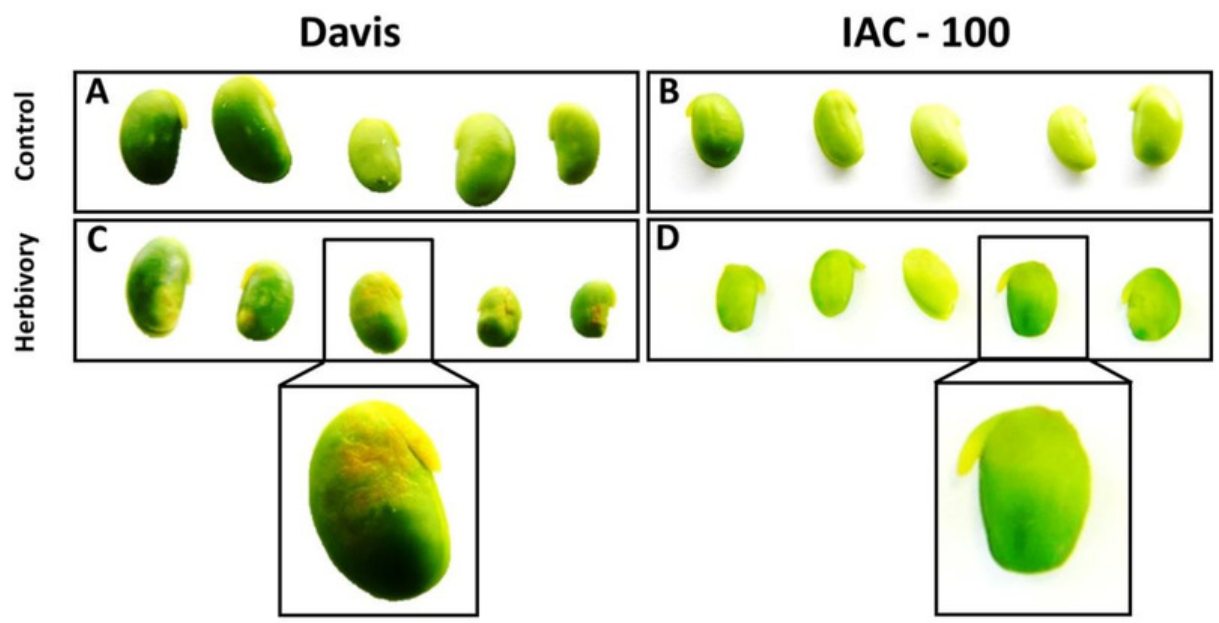


Figure 2

Mean hardness of soybean pods in R6

Means values (bars) and SEM (whiskers) are shown. Different letters are significantly different $(p<0.05-\mathrm{n}=17)$. Data source in Supplemental Information. 


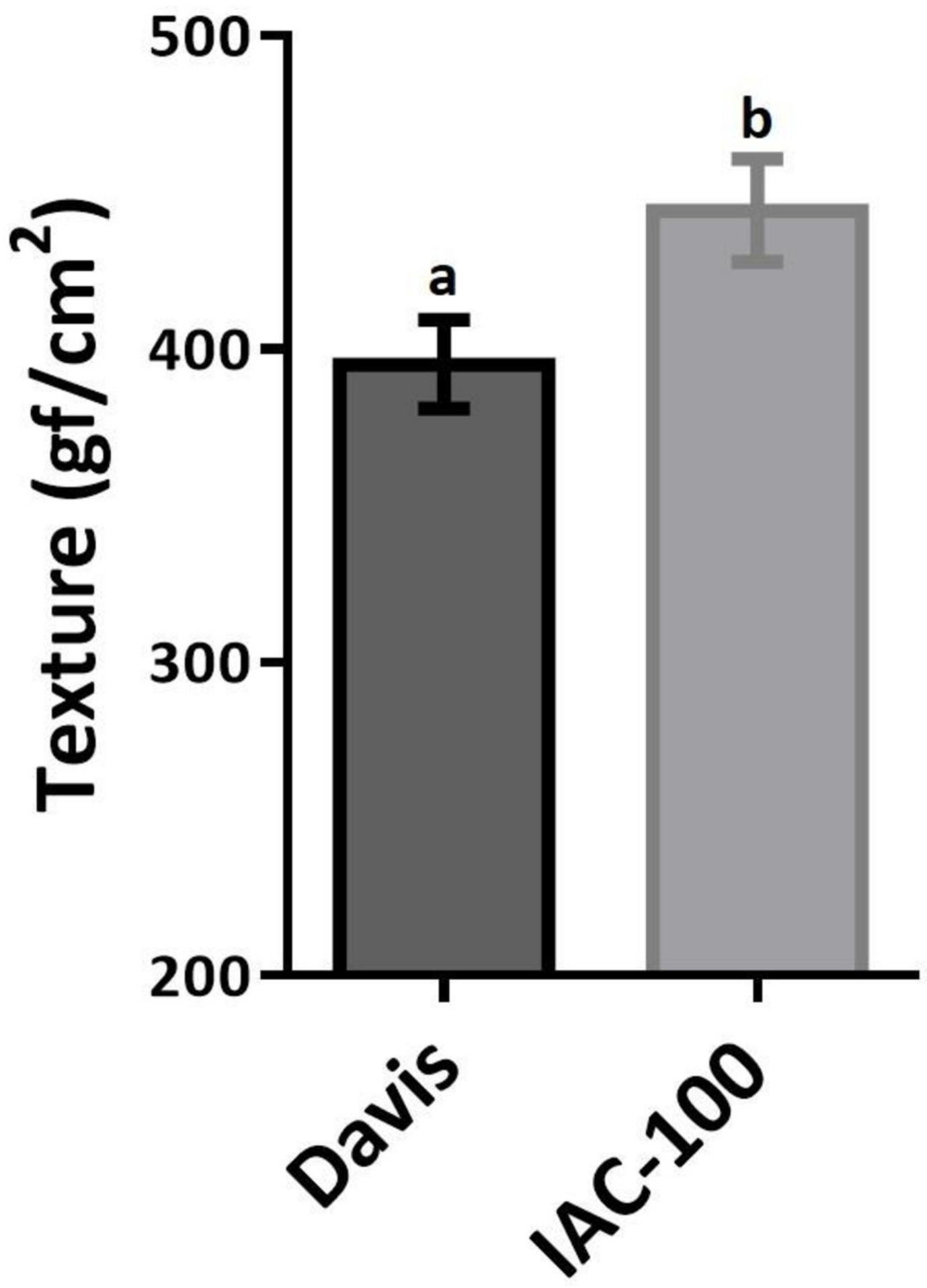




\section{Figure 3}

Oxidative stress analysis in seeds of different soybean genotypes damaged by Nezara viridula and their respective controls without herbivory

(A) Cluster analysis of oxidative stress enzymes. (B) Catalase activity. (C) Superoxide dismutase activity. (D) Guaiacol peroxidase activity. Means values (dots and squares) and SEM (whiskers) are shown. Different letters are significantly different $(p<0.05)$. Data source in Supplemental Information. 


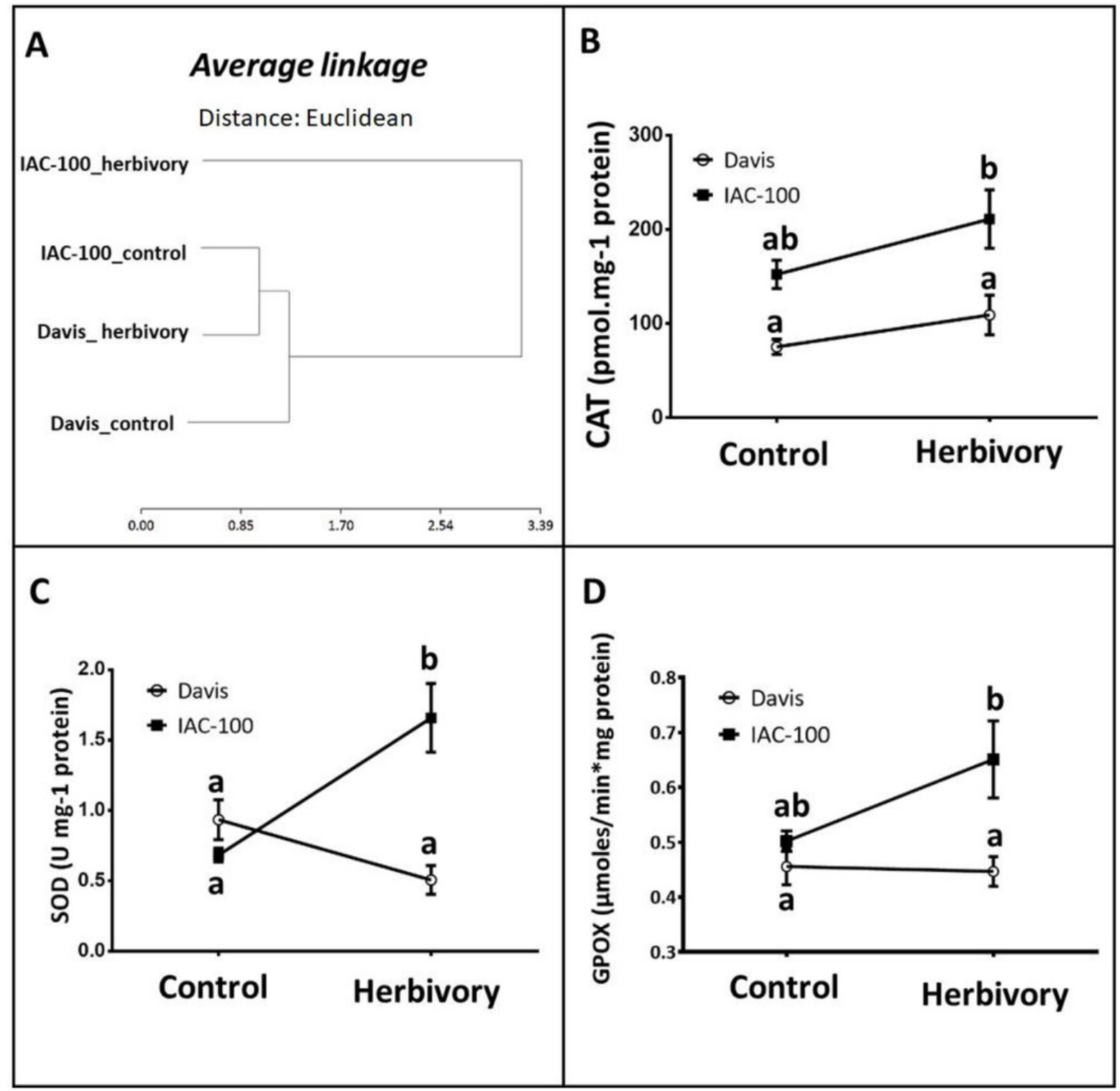


Figure 4

Gene expression by Real-Time PCR of LOX1 and LOX2 in soybean seeds, either undamaged and damaged by Nezara viridula

(A) LOX1. (B) LOX2. Gene expression is relative to the soybean elongation factor (ELF1b).

Means values (bars) and SEM (whiskers) are shown. Different letters are significantly

different $(p<0.05)$. Data source in Supplemental Information. 

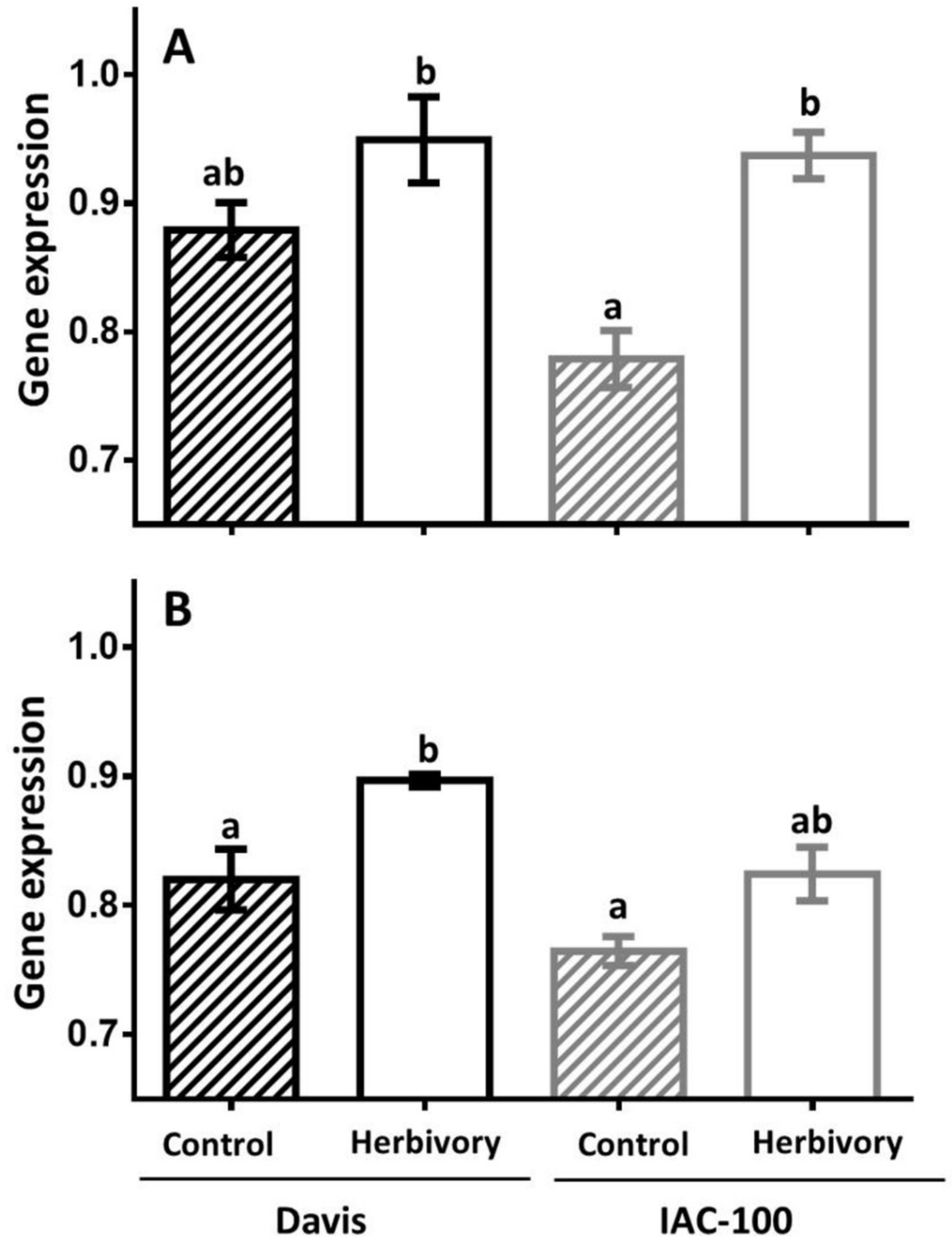


\section{Figure 5}

Isoflavonoid concentration in seeds of cultivars Davis and IAC-100 damaged by stink bugs and their respective controls without herbivory

(A) Daidzin concentration. (B) Genistin concentration. (C) Daidzein concentration. Means values (bars) and SEM (whiskers) are shown. Different letters are significantly different $(p<0.05)$. Data source in Supplemental Information. 

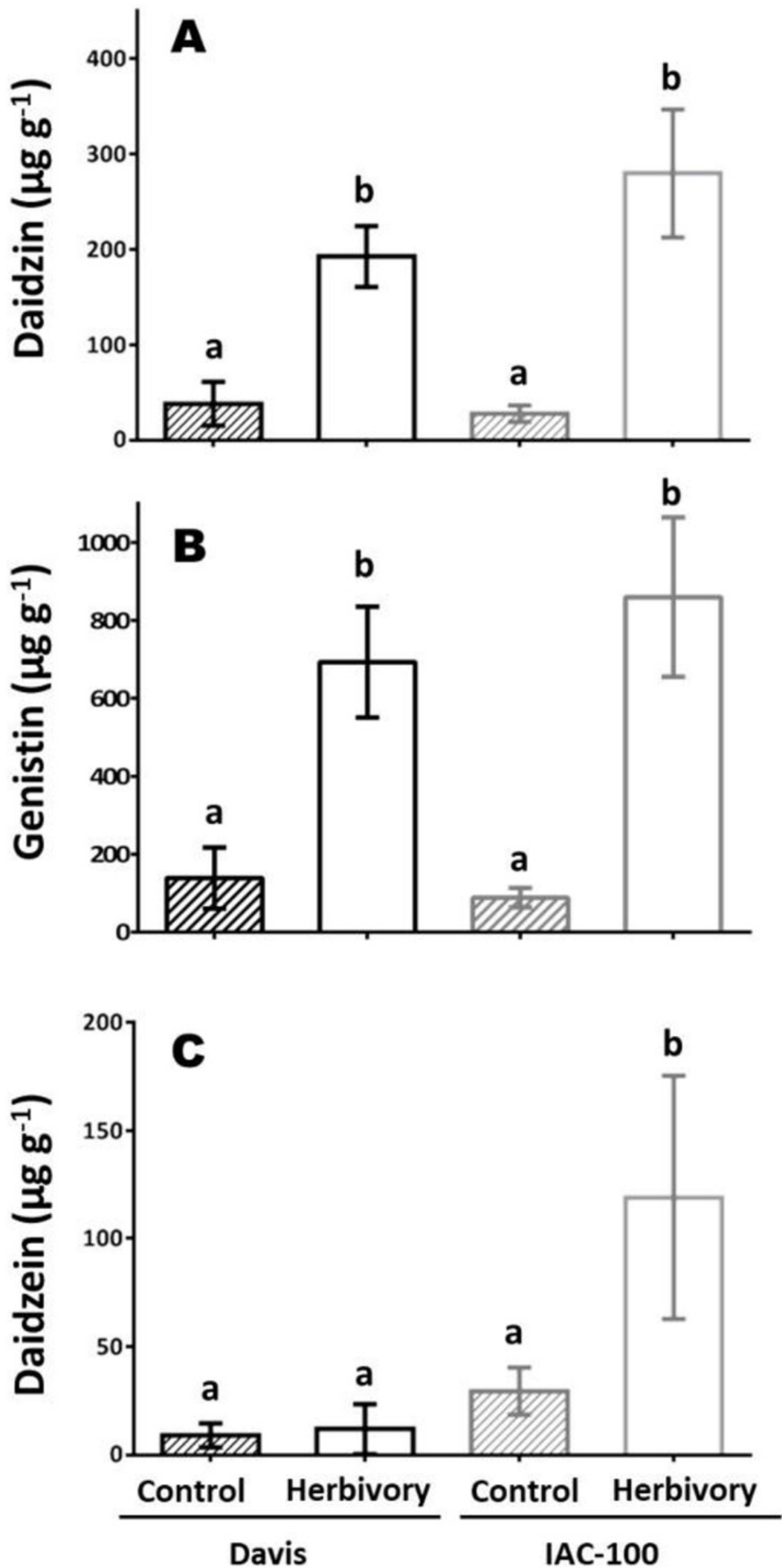
Table $\mathbf{1}$ (on next page)

LOX1, LOX2 and ELF1b primer sequences 
1

\begin{tabular}{|c|c|c|c|}
\hline LOX1 & $\begin{array}{l}\text { Forward: } \\
\text { Reverse: }\end{array}$ & $\begin{array}{l}\text { 5' CTGGTGTAAATCCCTGCGTAA 3' } \\
\text { 5' TACCAAGTGCCTCGTCCATT 3' }\end{array}$ & Chen et al. (2012) \\
\hline LOX2 & $\begin{array}{l}\text { Forward: } \\
\text { Reverse: }\end{array}$ & $\begin{array}{l}\text { 5' AGATGGTTGCGGGTGTAAAT 3', } \\
\text { 5' GGGCATCTGCTGTTATCTTAC 3', }\end{array}$ & Chen et al. (2012) \\
\hline$E L F 1 b$ & $\begin{array}{l}\text { Forward: } \\
\text { Reverse: }\end{array}$ & $\begin{array}{l}\text { 5'- GTTGAAAAGCCAGGGGACA -3' } \\
\text { 5'- TCTTACCCCTTGAGCGTGG -3' }\end{array}$ & l. (2008) \\
\hline
\end{tabular}

